\title{
Premature Weaning of Rat Pups Results in Prolongation of Neonatal Tolerance to Hyperoxia
}

\author{
LEE FRANK
}

Departments of Medicine and Pediatrics, University of Miami School of Medicine, Miami, Florida 33101

\begin{abstract}
Neonatal rats usually lose their marked tolerance to hyperoxia at about 1 mo of age. We examined the hypothesis that the marked dietary change that occurs at weaning might be important to this loss of $\mathrm{O}_{2}$ tolerance. We, therefore, prematurely weaned rat pups at 15-17 d of age, expecting to find an earlier loss of $\mathrm{O}_{2}$ tolerance. Surprisingly, the prematurely weaned rats showed consistently prolonged relative $\mathrm{O}_{2}$ tolerance compared with normally weaned rats at all ages tested from 35-85 d of life. For example, when challenged with $>95 \% \mathrm{O}_{2}$ exposure for $7 \mathrm{~d}$, the composite survival rate of the prematurely weaned rats (at 35-85 d of age) was nearly twice that of the normally weaned group $(83$ of $107=78 \%$ versus 44 of 107 $=41 \%, p<0.01$ ). In the two experimental groups, nearly all comparative parameters examined were similar, including: 1) growth rate; 2) lung DNA, RNA, and protein; 3) lung antioxidant enzymes and enzyme responses to hyperoxia; 4) lung morphometry; and 5) lung elastin and collagen content. Only serum corticosterone and triiodothyronine levels differed considerably in the two groups. We conclude that premature weaning has a very marked and sustained positive effect on the relative retention of $\mathrm{O}_{2}$ tolerance in the growing rat. (Pediatr Res 29: 376-380, 1991)
\end{abstract}

Abbreviations

$T_{3}$, triiodothyronine

MDA, malonaldehyde

Neonatal animals of many species are quite resistant to pulmonary $\mathrm{O}_{2}$ toxicity and survive much longer in hyperoxia $(>95 \%$ $\mathrm{O}_{2}$ ) than the adults of these species $(1,2)$. However, this relative tolerance to hyperoxia wanes at about 1 mo of life (3). The basis for this age-related loss of $\mathrm{O}_{2}$ tolerance is not known.

We hypothesized that the chronologically related event of weaning and the rather drastic change in diet that occurs at weaning-from a high fat, low carbohydrate milk diet to a low fat, high carbohydrate rat pellet diet (protein contents equivalent) - could be associated with the subsequent loss of $\mathrm{O}_{2}$ tolerance. We also hypothesized that maintaining weanling rats on a rat milk diet might extend their period of tolerance to hyperoxia. However, lacking a truly appropriate rat milk diet substitute, we elected instead to first try the opposite approach, i.e. to determine whether premature weaning of suckling rats (d 15-17) to a mashed pellet diet would result in an earlier or more profound loss of $\mathrm{O}_{2}$ tolerance in comparison to rat pups normally weaned at 24-25 d of age. To our surprise, the prematurely weaned rat pups showed a prolonged relative $\mathrm{O}_{2}$ tolerance to hyperoxia.

Received April 6, 1990; accepted November 16, 1990.

Correspondence: Lee Frank, M.D., Ph.D., Pulmonary Research (R-120), University of Miami School Medicine, P.O. Box 016960, Miami, FL 33101.

Supported by NIH Grant No. HL26029.

\section{MATERIALS AND METHODS}

Animals. Newborn rat litters were obtained from our own approved breeding colony under veterinary supervision by the Division of Animal Care, University of Miami. Several litters were pooled at birth and redistributed to the dams in litter sizes of 10-12 pups. Dams were maintained on water and standard rat pellet diets (Rodent Laboratory Chow, no. 5001, Ralston Purina Co., St. Louis, MO) ad libitum, and on a $12 \mathrm{h:12}$ h dark/ light cycle. Litters were normally weaned at $24-25 \mathrm{~d}$ of age to the rat pellet diet. Premature weanlings were removed from their dams at d 15-17 of age and put on a mashed pellet diet for several days and then whole rat pellets. Water was provided ad libitum. Daily growth changes were recorded for the two groups of weanlings. (The total protocol was preapproved by the University Animal Care and Animal Welfare Committee.)

Exposures to hyperoxia. Normally weaned and prematurely weaned rats were exposed together to $>95 \% \mathrm{O}_{2}$ at various ages between 30 and $85 \mathrm{~d}$ of life. Exposures to $\mathrm{O}_{2}$ were conducted in $3.5-\mathrm{ft}^{3}$ exposure chambers constructed from modified clear plastic nursery isolettes (model 86; Air Shield, Hatboro, PA). Exposure conditions were carefully controlled and monitored (96$98 \% \mathrm{O}_{2},<0.5 \% \mathrm{CO}_{2}, 24-27^{\circ} \mathrm{C}, 50-75 \%$ humidity) with gas analyzers and in-chamber thermometer-hygrometers. All $\mathrm{O}_{2}$ exposures were continuous, except for 10-15 min daily when the chambers were opened to change the bedding and supply fresh food and water. Exposures were for $72 \mathrm{~h}$ or for $7 \mathrm{~d}$. $\mathrm{O}_{2}$-induced lung damage was assessed by comparative survival, pleural fluid accumulation, lung wet/dry weights, lung weight/body weight ratios, and gross and light microscopic pathology.

Biochemical and blood studies. Blood from anesthetized rats (pentobarbital, $40 \mathrm{mg} / \mathrm{kg}$, intraperitoneally) was collected from the inferior vena cava, and the serum levels of $\mathrm{T}_{3}$ and corticosterone were measured by RIA using specific RIA kits with accompanying instructions $\left(\mathrm{T}_{3}\right.$, Cambridge Technology, Inc. Cambridge, MA; corticosterone, Radioassay Systems Laboratories, Carson, CA). All blood was collected between 1000 and $1200 \mathrm{~h}$. Serum was frozen at $-70^{\circ} \mathrm{C}$ before analysis.

Lung biochemical parameters were determined on rats exsanguinated by cutting the great vessels in the abdomen after deep pentobarbital anesthesia. The lungs were then rapidly perfused free of blood via the pulmonary artery with cold isotonic phosphate buffer $(0.1 \mathrm{M}$ potassium phosphate, $0.15 \mathrm{M} \mathrm{KCl}, \mathrm{pH} 7.4)$. After the lungs were dissected free of nonpulmonary tissues, they were weighed and homogenized in cold hypotonic phosphate buffer $(0.005 \mathrm{M}$ potassium phosphate, $\mathrm{pH} 7.8)(10: 1$; vol/wt) in a polytron (Brinkman Instruments Co., Westbury, NY), and subsequently assayed for DNA (4), RNA (5), and protein content (6), and for the antioxidant enzymes superoxide dismutase (7), catalase (8), and glutathione peroxidase (9) using standard spectrophotometric assays. Purified reference standards for all these assays were obtained commercially (Sigma Chemical Co., St. Louis, MO).

Hydroxyproline values were determined in perfused lungs by the acid hydrolysis spectrophotometric method of Woessner (10). 
Elastin was determined by the spectrophotometric method of Naum and Morgan (11).

We also assayed the lungs for lipid peroxidation products by using the MDA assay of Ohkawa et al. (12). This assay involved mixing $0.3 \mathrm{~mL}$ of lung homogenate, $0.2 \mathrm{~mL}$ of $8.1 \% \mathrm{SDS}$, and $1.5 \mathrm{~mL}$ of $20 \%$ acetic acid (adjusted to $\mathrm{pH} 3.5$ with $\mathrm{NaOH}$ ) with $2.0 \mathrm{~mL}$ of aqueous thiobarbituric acid. After $60 \mathrm{~min}$ of heating at $95^{\circ} \mathrm{C}$, the solution was cooled, mixed vigorously with $5.0 \mathrm{~mL}$ of $n$-butanol, and subjected to centrifugation $(2000 \times g$ for 15 $\min )$. The absorbance of the upper organic layer was determined at $532 \mathrm{~nm}$ and compared with a standard curve of tetraethoxy propane reagent.

Microscopic studies. Lungs from killed rats of various ages were inflated with $10 \%$ buffered formaldehyde via tracheal cannula at a constant pressure of $20 \mathrm{~cm} \mathrm{H}_{2} \mathrm{O}$ (fixative). Lung volumes were determined by water displacement immediately after inflation and again just before sectioning $48 \mathrm{~h}$ later to correct for shrinkage. Similarly oriented sections of each lobe were prepared for hematoxylin and eosin staining and subsequent evaluation by light microscopy. For the morphometric studies, coded slides were examined at $\times 450$ with an integrating eyepiece with a simple square-grid pattern (square grid with five horizontal lines and 25 intercept bars, model cPLW $\times 10 / 18$ eyepiece, Zeiss Optical, Thornwood, NY). A minimum of 30 lung fields from each of three different lung sections per animal were examined.

To calculate the mean linear intercept $(\mathrm{Lm}$, the average distance between alveolar walls), the formula $\mathrm{Lm}=\mathrm{n} \cdot \mathrm{L} / \mathrm{\epsilon}$ i was used, where $n$ is the number of grid lines counted, $\mathrm{L}$ is the length of line, and $\epsilon \mathrm{i}$ is the sum of alveolar intercepts. To calculate the internal surface area (ISA), we used the formula ISA $=4 . \mathrm{V} / \mathrm{Lm}$, where $\mathrm{V}$ is the shrinkage-corrected lung volume by water displacement. The percent air space was determined by dividing the number of "hits" (intercept bars) falling on air spaces by the total number of intercept bars falling on lung tissue plus air spaces. All formulas and counting methods used are derived from Weibel (13).

Statistical analysis. For comparison of biochemical differences between the two groups of weanling rats, unpaired $t$ test analysis was done. For comparing values for the two hyperoxic groups versus air control values, one-way analysis for variance was done followed by Duncan's multiple range test. Survival rates were compared statistically by $\chi^{2}$ testing (14). For all statistical tests, a $p<0.05$ value was considered to represent a significant difference between the compared values.

\section{RESULTS}

There were no differences in growth rate for the prematurely weaned versus the normally weaned rat pups, nor were lung weight/body weight ratios different at any chronologic time point. Similarly, lung protein, DNA, and RNA content and RNA/DNA ratio were longitudinally similar in the two groups of weanlings (Table 1).

Figure 1 illustrates the comparative survival data for the normally weaned and prematurely weaned rats exposed to hyperoxia $\left(>95 \% \mathrm{O}_{2} \times 72 \mathrm{~h}\right)$ at the indicated age intervals. At all ages tested, consistently increased tolerance to hyperoxia was observed in the prematurely weaned group of rats [composite 72-h survival rates $=104$ of $199(52 \%)$ normally weaned versus 161 of 198 $(81 \%)$ prematurely weaned; $p<0.01$ ].

Table 2 shows comparative pathologic changes in the hyperoxic survivors of the two experimental groups, indicating lesser evidence of hyperoxic lung damage in the prematurely weaned rat group. Qualitative assessment of coded slides similarly indicated less common and less diffuse $\mathrm{O}_{2}$ toxicity changes in the prematurely weaned animals. Whereas both groups had prominent perivascular-peribronchiolar edema, areas of intraalveolar edema or hemorrhage were seen almost exclusively in the $\mathrm{O}_{2}$ exposed normally weaned rat lungs.

Lung MDA levels, reflective of lipid peroxidation, were also significantly higher in the more $\mathrm{O}_{2}$ susceptible normally weaned group than the more $\mathrm{O}_{2}$ tolerant prematurely weaned group. Values after $72 \mathrm{~h}$ in $>95 \% \mathrm{O}_{2}$ (age $40 \mathrm{~d}, n=4$ per group) were $0.032 \pm 0.003 \mathrm{nmol} \mathrm{MDA} / \mathrm{g}$ lung (air controls), $0.039 \pm 0.006$ (prematurely weaned), and $0.061 \pm 0.017$ (normally weaned); $p$ $<0.05$ for normally weaned in $\mathrm{O}_{2}$ versus both other groups.

That the relative protection from $\mathrm{O}_{2}$ toxicity manifested in the prematurely weaned group (Fig. 1) does not merely reflect a delay in the onset of severe $\mathrm{O}_{2}$ toxicity progressing to lethality is evident from the survival results in Figure 2 . With hyperoxic exposure extended to $7 \mathrm{~d}\left(>95 \% \mathrm{O}_{2}\right)$, the prematurely weaned animals still demonstrated double the survival rate of the normally weaned group ( 78 versus $41 \%$ ).

We were unable to explain the difference in survival rates on the basis of disparate lung antioxidant enzyme responses to hyperoxia. Baseline antioxidant enzyme levels (superoxide dismutase, catalase, and glutathione peroxidase) were similar in the two experimental groups; Figure 3 shows the similar elevation in lung enzymes in both groups of weanlings during $\mathrm{O}_{2}$ exposure at age $40 \mathrm{~d}$ and an essentially similar lack of any significant antioxidant enzyme response to $>95 \% \mathrm{O}_{2}$ exposure at age $60 \mathrm{~d}$.

Because of our previous experience with altered lung structural development producing improved $\mathrm{O}_{2}$ tolerance in castrated weanling rats (15), we examined comparative morphometry in the two present experimental groups of animals. No altered lung structural changes in the two groups of weanling rats were noted (data not shown). Similar specific lung volumes, mean airspace size, internal surface area for respiratory exchange, and internal surface area per $100 \mathrm{~g}$ body weight were present.

Similarly, because elastin and collagen deposition are actively ongoing processes around the time of weaning in the rat $115-$ 17), we compared lung connective tissue development in our two experimental groups. No difference in collagen and elastin content in the lungs of the two weanling rat groups was observed. Hydroxyproline and elastin concentration ( $\mathrm{mg} / \mathrm{g}$ dry lung wt) at age $52 \mathrm{~d}$ were $8.87 \pm 0.52$ and $8.76 \pm 1.10$, and $68.2 \pm 12.7$ and $62.7 \pm 13.6$, respectively, for the normally and prematurely weaned animals ( $n=6$ per group).

Finally, because serum levels of corticosterone and $\mathrm{T}_{3}$ are low in early postnatal life but begin to rise rapidly toward the time

Table 1. Comparative lung biochemistries of prematurely weaned and normally weaned rat pups at various ages*

\begin{tabular}{lccccc}
\hline & Lung protein & Lung DNA & Lung RNA & Protein/DNA & RNA/DNA \\
\hline Age 28 d & & & & & \\
$\quad$ Normally weaned (15) & 55.7 & 5.95 & 2.71 & 9.37 & 0.463 \\
$\quad$ Prematurely weaned (15) & 59.0 & 5.89 & 3.17 & 10.02 & 0.540 \\
Age 42 d & & & & & \\
$\quad$ Normally weaned (9) & 104.8 & 8.13 & 3.92 & 12.91 & 0.485 \\
$\quad$ Prematurely weaned (9) & 95.7 & 8.51 & 4.28 & & 0.503 \\
Age 75 d & 113.6 & 9.77 & 5.15 & 11.57 & 0.528 \\
$\quad$ Normally weaned (5) & 113.0 & 10.6 & 5.31 & 10.66 & 0.501 \\
$\quad$ Prematurely weaned (5) & & & & & \\
\hline
\end{tabular}

* Values are mean total lung contents $(\mathrm{mg})$ at ages indicated for $(n)$ samples. No differences between groups at any age are significant at $p<0.05$ level. 


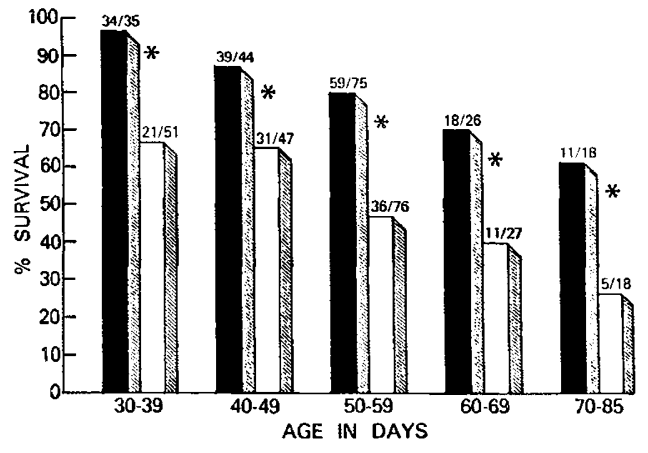

Fig. 1. Comparative survival rates for the prematurely weaned and normally weaned rat pups at the age intervals indicated. At all ages tested, the prematurely weaned group (solid bars) had statistically significant higher survival rates than the normally weaned group (open bars) during exposure to $>95 \% \mathrm{O}_{2}$ for $72 \mathrm{~h}\left({ }^{*} p<0.05-0.01\right)$.

of weaning and both may affect lung growth and development $(18,19)$, we compared serum hormone levels in our two groups of weanling pups (Fig. 4). Corticosterone showed a large rise in serum level about a week earlier than normal in the prematurely weaned animals, and serum levels remained comparatively elevated to $\mathrm{d} 45$. The opposite effect of premature weaning occurred with $T_{3}$, with continued relative depression of serum $T_{3}$ until $d$ 45 compared with the normally weaned rat hormone levels.

\section{DISCUSSION}

One of the more intriguing unsolved mysteries of $\mathrm{O}_{2}$ toxicity is the age-related pattern of tolerance to hyperoxia and progressive loss of $\mathrm{O}_{2}$ tolerance by neonatal animals beginning at about 1 mo of age $(1,3,20,21)$. Before 1 mo of age, nearly $100 \%$ of neonatal rats will survive prolonged exposure to $>95 \% \mathrm{O}_{2}$, yet by 2 mo of age $<25 \%$ will survive similar $\mathrm{O}_{2}$ challenge and the survivors will manifest severe $\mathrm{O}_{2}$-induced lung damage. We and others have been able to associate the neonatal animal's tolerance to high $\mathrm{O}_{2}$ with the rapid biochemical responsiveness of the immature animal's lung to hyperoxia, i.e. the neonatal lung manifests a marked increase in its antioxidant enzyme protective system shortly after the onset of exposure to high $\mathrm{O}_{2}(2,20,21)$. This protective biochemical response is not seen in adult animals, which survive poorly in hyperoxia $(2,20,22)$. Recently, these findings were reinforced with the demonstration of a rapid pretranslational induction by hyperoxia of pulmonary antioxidant enzyme mRNA in neonatal rats, but no similar effect on enzyme mRNA in simultaneously $\mathrm{O}_{2}$-exposed adult animals (23).

We have previously approached the question of why neonatal animals lose their $\mathrm{O}_{2}$ tolerance at about 1 mo of age by examining the effects of castration at $20 \mathrm{~d}$ of age, just before the pubertal surge in sexual hormones occurs in rat pups. Male castration, which served to abrogate the serum testosterone hormone surge at approximately 1 mo of age, both altered subsequent lung growth and prolonged relative $\mathrm{O}_{2}$ tolerance (15). The significantly enlarged lung volumes and mean lung airspace sizes were determined to be the most likely factors related to the prolongation of relative $\mathrm{O}_{2}$ tolerance in the castrated male rats. In turn, the altered hormonal milieu (increased serum growth hormone and glucocorticoid levels plus decreased testosterone) was postulated to have caused the altered lung growth pattern in the castrated rats (15).

Weaning is a key event occurring at approximately 1 mo of age in the rat because of the rather drastic change in dietary composition it entails and the possible effect of altered diet on the developing lung and its susceptibility to hyperoxia. Our prematurely weaned rats experienced a sudden switch from a milk diet low in carbohydrate $(3 \%)$ and high in fat $12.5 \%$, primarily saturated fatty acids) $8-10 \mathrm{~d}$ before the control weanlings were switched from milk to the high carbohydrate $(25 \%)$ and low fat $(4.5 \%$, primarily unsaturated fatty acids) rat pellet diet $(24,25)$. The dietary change at weaning results in rapid increases in enzymes involved in lipogenesis and concurrent rapid decreases in enzymes involved in glucogenesis and fatty acid oxidation (26-28). However, as opposed to these metabolic changes in the liver, fatty tissue, and gastrointestinal tract, no information is available about dietary-induced lung metabolic, enzymic, or growth changes specifically associated with weaning. Wide changes in hormonal levels also occur around the time of weaning, with rapidly decreased serum glucagon, increased insulin, and a rapid increase in serum glucocorticoid hormone (18, $29,30)$. Plasma $T_{3}$ also rises just before the time of normal weaning in rats (31). Other hormonal factors that normally increase in rats around the normal time of weaning include growth hormone (32) and somatomedin C (33). $\beta$-Adrenergic receptors in the rat lung markedly increase between $d 15-28$, and this change in receptor density is related to the normal rise in serum $\mathrm{T}_{3}$ levels at this time (34). The rise in serum growth hormone levels at approximately $20 \mathrm{~d}$ of age is also dependent upon the normal rise of $\mathrm{T}_{3}$ and the rise in glucocorticoid hormones at this time (35). These three hormones, which each rise around the time of weaning, have known lung growth effects $(36,37)$.

The premature switch (age 15-17 d) to a weanling diet in our studies resulted in a dramatic retention of relative tolerance to hyperoxia over the next 2 mo of life. The mechanism(s) of our observed protective effect associated with premature weaning remains unclear. We noted that the important lung antioxidant enzyme responses to hyperoxia were similar in the two groups of weanling animals. No meaningful differences in lung structure (morphometry) were found in comparing our two groups of weanling rats at several later ages. Similarly, lung elastin and collagen deposition were similar in the growing lungs of the two experimental groups. The very striking differences in the patterns of serum $\mathrm{T}_{3}$ and corticosterone levels are intriguing, but just how they might have affected $\mathrm{O}_{2}$ tolerance per se is difficult to define. Elevated corticosteroid levels by exogenous means actually tend to exacerbate the course of $\mathrm{O}_{2}$ toxicity $(38,39)$. Conceivably, the suppressed serum $\mathrm{T}_{3}$ activity in the prematurely weaned pups was associated with depressed $\mathrm{O}_{2}$ consumption and reduced $\mathrm{O}_{2}$ radical production (not measured), but by $45 \mathrm{~d}$ of life $T_{3}$ levels were equivalent in the two experimental groups and relative $\mathrm{O}_{2}$ tolerance persisted in the prematurely weaned rat group.

There is good evidence that the lungs will rather rapidly assume a fatty acid composition that reflects the dietary fatty acid profile and much theoretical but less experimental evidence that a more saturated fatty acid diet has a relative protective effect against $\mathrm{O}_{2}$ toxicity (40-42). This may be because polyunsaturated fatty acids are prone to $\mathrm{O}_{2}$ free radical attack and lipid peroxidation, but

Table 2. Comparative pathologic changes in two experimental groups ( $\mathrm{h}$ ) exposed to hyperoxia $>95 \% \mathrm{O}_{2}$ for $\left.72 \mathrm{~h}\right)$

\begin{tabular}{llll}
\hline \multicolumn{1}{c}{ Group } & Pleural fluid $(\mathrm{mL})$ & Lung wt/body wt & Lung wet/dry wt \\
\hline Air controls & $0.06 \pm 0.06(10)$ & $0.433 \pm 0.107(12)^{*}$ & $4.96 \pm 0.15(8)^{*}$ \\
$\mathrm{O}_{2}$ normally weaned & $2.85 \pm 3.09(11) \dagger$ & $1.015 \pm 0.402(13)$ & $5.54 \pm 0.03(9)$ \\
$\mathrm{O}_{2}$ prematurely weaned & $0.87 \pm 0.13(11)$ & $0.744 \pm 0.119(13) \ddagger$ & $5.34 \pm 0.26(9) \ddagger$ \\
\hline
\end{tabular}

$* p<0.01$ vs both $\mathrm{O}_{2}$ groups.

$\dagger p<0.05$ compared with both other groups.

$\ddagger p<0.05$ vs other $\mathrm{O}_{2}$ group. 


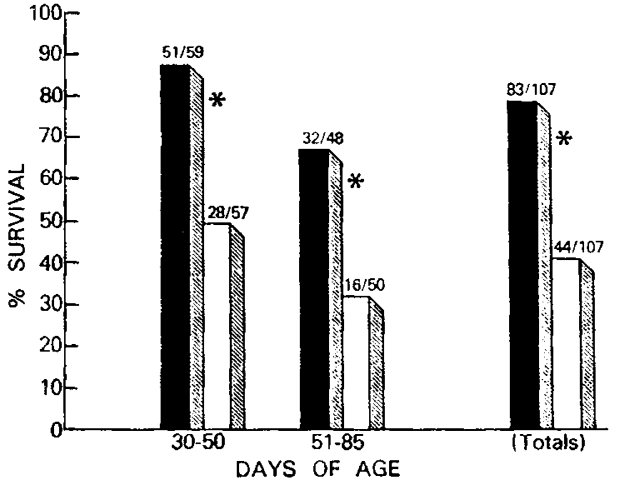

Fig. 2. Comparative survival rates when $>95 \% \quad \mathrm{O}_{2}$ exposure was extended to $7 \mathrm{~d}$. At both younger (30-50 d of age) and older ages (51$85 \mathrm{~d}$ of age), the prematurely weaned group of rats (solid bars) had statistically significant improved survival rates compared with the normally weaned animals (open bars) $\left({ }^{*} p<0.01\right.$ ). The prematurely weaned rats also had significantly improved total survival rates in $>95 \% \mathrm{O}_{2}$ for $7 \mathrm{~d}(78$ vs $41 \%)$.

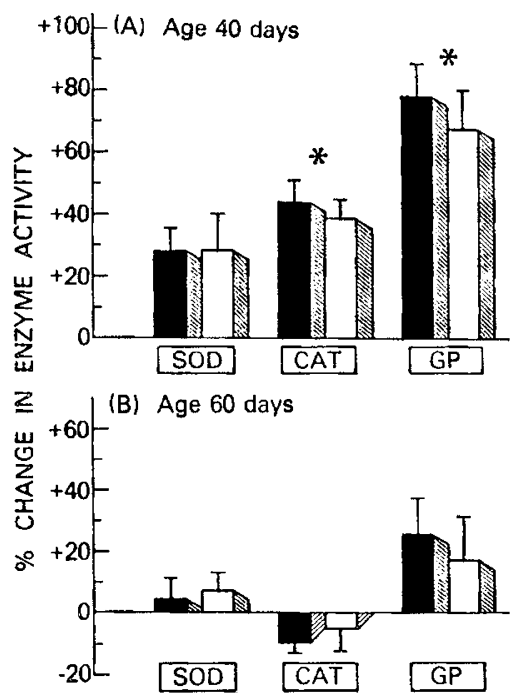

Fig. 3. Changes in lung antioxidant enzyme activity during exposure to $>95 \% \mathrm{O}_{2}$ for $72 \mathrm{~h}$. The values were calculated as activity units $/ \mathrm{mg}$ DNA and are plotted here as \% change compared with air control enzyme activity levels. $A$, at age $40 \mathrm{~d}$, both experimental groups-the prematurely weaned (solid bars) and the normally weaned rats (open bars)-manifest similar increases in lung superoxide dismutase (SOD), catalase $(C A T)$, and glutathione peroxidase $(G P)$ activities compared with air control levels (the zero value) $\left({ }^{*} p<0.05, n=6\right.$ per group, mean + SEM bars). $B$, by age $60 \mathrm{~d}$, both experimental groups show a similar lack of any significant antioxidant enzyme increase during $\mathrm{O}_{2}$ exposure ( $n=6$ per group, mean \pm SEM bars). Air control enzyme values: SOD $28.5 \pm 2.2$ units/mg DNA; CAT $573 \pm 16 ;$ and GP $1.58 \pm 0.14$

saturated fatty acids are resistant to lipid peroxidation damage (43). We do not believe that the improved survival of the prematurely weaned animals was related to their lung fatty acid profile. Although these rat pup lungs might be expected to have a more unsaturated fatty acid composition (due to pellet versus milk diet) before the normally weaned pups, their $\mathrm{O}_{2}$ tolerance was obviously not impaired by this. Moreover, in the later ages tested, both experimental groups might be expected to have attained very similar lung lipid profiles reflecting the same rat pellet (polyunsaturated fat-rich) diet.

We conclude that the premature weaning of rat pups results in a marked prolongation of relative tolerance to hyperoxia. After examining all the comparative parameters tested, we do not yet have a satisfactory explanation for the effectiveness of

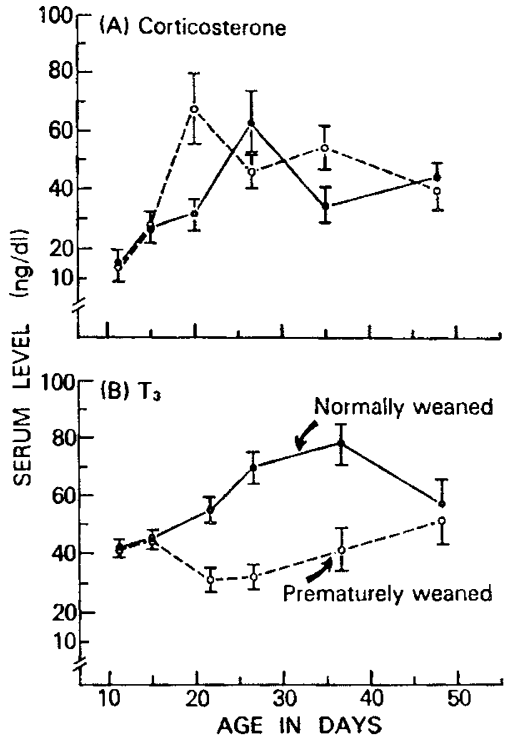

Fig. 4. Comparative serum hormone levels, ages 12 to $50 \mathrm{~d}$, in the two groups of experimental animals (mean $\pm 1 \mathrm{SD} ; n=3$ per time point). $A$, corticosterone, showing earlier rise and sustained elevation in prematurely weaned $(O)$ rats compared with the normally weaned animals $(\bullet) . B, \mathrm{~T}_{3}$, showing sustained depression of $\mathrm{T}_{3}$ in the prematurely weaned rats $(O)$ vs the normally weaned group $(\bullet)$. Values for both hormones in both groups become equivalent by age $50 \mathrm{~d}$.

early weaning on extending the normal period of neonatal $\mathrm{O}_{2}$ tolerance.

Acknowledgments. The author thanks Miguel Martinez, B.S., for his excellent technical assistance with these studies and Martha Sanchez for her generous assistance with the manuscript preparation.

\section{REFERENCES}

1. Yam J, Frank L, Roberts RJ 1978 Oxygen toxicity: comparison of lung biochemical responses in neonatal and adult rats. Pediatr Res 12:115-119

2. Frank L, Bucher JR, Roberts RJ 1978 Oxygen toxicity in neonatal and adult animals of various species. J Appl Physiol 45:699-704

3. Frank L 1982 Maturational aspects of oxidant-induced lung injury. In: Hunt RE, Smith MK, Work D (eds) Environmental Factors in Human Growth and Development. Cold Spring Harbor Laboratory, New York, pp 17-31

4. Richards GM 1974 Modification of the diphenylamine reaction giving in creased sensitivity and simplicity in the estimation of DNA. Anal Biochem 57:369-376

5. Schneider WC 1956 Determination of nucleic acids in tissue by pentose analysis. In: Colowick SP, Kaplan NO (eds) Methods in Enzymology. Academic, New York, pp 680-684

6. Schacterle RE, Pollack RL 1973 A simplified method for the quantitative assay of small amounts of protein in biological material. Anal Biochem 51:654655

7. McCord JM, Fridovich I 1969 Superoxide dismutase: an enzyme function of erythrocuprein (hemocuprein). J Biol Chem 244:6049-6055

8. Holmes RS, Masters CJ 1970 Epigenetic interconversion of the multiple forms of mouse liver catalase. FEBS Lett 11:45-48

9. Paglia DE, Valentine WN 1967 Studies on the quantitative and qualitative characterization of erythrocyte glutathione peroxidase. J Lab Clin Med 70:158-169

10. Woessner Jr JF 1961 The determination of hydroxyproline in tissue and protein samples containing small proportions of this amino acid. Arch Biochem Biophys 93:440-447

11. Naum Y, Morgan TE 1973 A microassay for elastin. Anal Biochem 53:392396

12. Ohkawa H, Ohishi N, Yagi K 1979 Assay for lipid peroxides in animal tissues by thiobarbituric acid reaction. Anal Biochem 95:351-358

13. Weibel ER 1963 Morphometry of Human Lung. Academic, New York, pp 1-

14. Steel RGD, Torrie JG 1960 Principles and Procedures of Statistics. McGraw, New York, pp 90-109

15. Neriishi K, Frank L 1984 Castration prolongs tolerance of young male rats to pulmonary $\mathrm{O}_{2}$ toxicity. Am J Physiol 247:R475-R481

16. Nardell EA, Brody SB 1982 Determinants of mechanical properties of rat lung during postnatal development. J Appl Physiol 53:140-148 
17. Schellenberg J-C, Liggins GC, Stewart AW 1987 Growth, elastin concentration, and collagen concentration of perinatal rat lung: effects of dexamethasone. Pediatr Res 21:603-607

18. Back DW, Sohal PS, Angel JF 1985 Effects of diet and selected hormones on the activities of hepatic malic enzyme and glucose-6-phosphate dehydrogenase in infant, prematurely weaned rats. J Nutr 115:625-632

19. Blake $\mathrm{HH}$, Henning SJ 1983 Weaning in the rat: a study of hormonal influences. Am J Physiol 244:R537-R543

20. Frank L 1985 Effects of oxygen on the newborn. Fed Proc 44:2328-2334

21. White CW 1988 Cellular mechanisms of oxidant injury and antioxidant defense. In: Bancalari E, Stocker JT (eds) Bronchopulmonary Dysplasia. Hemisphere, Cambridge, MA, pp 22-41

22. Frank L 1988 Extension of oxygen tolerance by treatment with endotoxin: means to improve its potential therapeutic safety in man. Exp Lung Res 14:987-1003

23. Hass MA, Iqbal J, Clerch LB, Frank L, Massaro D 1989 Rat lung CuZn superoxide dismutase. Isolation and sequence of a full-length cDNA and studies of enzymic induction. J Clin Invest 83:1241-1246

24. Smart JL, Stephens DN, Tonkiss J, Auestad NS, Edmond J 1984 Growth and development of rats artificially reared on different milk-substitutes. $\mathrm{Br} \mathrm{J}$ Nutr 52:227-237

25. Keen CL, Lonnerdal B, Clegg M, Hurley LS 1981 Developmental changes in composition of rat milk: trace elements, minerals, protein, carbohydrate and fat. J Nutr 111:226-230

26. Vernon RG, Walker DG 1968 Adaptive behavior of some enzymes involved in glucose utilization and formation in rat liver during the weaning period. Biochem J 106:331-338

27. Ferre P, Decaux J-F, Issad T, Girard J 1986 Changes in energy metabolism during the suckling and weaning period in the newborn. Reprod Nutr Dev 26:619-631

28. Hahn P, Kirby L 1973 Immediate and late effects of premature weaning and of feeding a high fat or high carbohydrate diet to weanling rats. J Nutr 103:690-696

29. Lee PC, Lebenthal E 1983 Early weaning and precocious development of small intestine in rats: genetic, dietary or hormonal control. Pediatr Res 17:645650
30. Hahn P, Girard J, Assan R, Frohlich J, Kervran A 1977 Control of blood cholesterol levels in suckling and weanling rats. J Nutr 107:2062-2066

31. Henning SJ 1981 Postnatal development: coordination of feeding, digestion, and metabolism. Am J Physiol 241:G199-G214

32. Philipps AF, Persson B, Hall K, Lake M, Skottner A, Sanengen T, Sara VR 1988 The effects of biosynthetic insulin-like growth factor-1 supplementation on somatic growth, maturation, and erythropoeisis in the neonatal rat. Pediatr Res 23:298-305

33. D'Ercole AJ, Underwood LE 1980 Ontogeny of somatomedin during development in the mouse. Serum concentrations, molecular forms, binding proteins, and tissue receptors. Dev Biol 79:33-45

34. Whitsett JA, Darovec-Beckerman C, Pollinger J, Moore Jr JJ 1982 Ontogeny of beta-adenergic receptors in the rat lung: effects of hypothyroidism. Pediatr Res 16:381-387

35. Evans RM, Birnberg NC, Rosenfeld MG 1982 Glucocorticoid and thyroid hormones transcriptionally regulate growth hormone gene expression. Proc hormones transcriptionally regulate

36. Morishige WK, Joun NS 1982 Influence of glucocorticoids on postnatal lung development in the rat: possible modulation by thyroid hormone. Endocrinology 111:1587-1594

37. Brody JS, Buhain WJ 1972 Hormone-induced growth of the adult lung. Am J Physiol 223:1444-1450

38. Newman JH, Fulkerson WJ, Kobayashi T, English D, Meyrick B, Brigham KL 1986 Effects of methylprednisolone on lung oxygen toxicity in awake sheep. J Appl Physiol 60:1386-1392

39. Gross NI Smith DM 1984 Methylprednisolone increases the toxicity of oxygen in adult mice. Mechanical and biochemical effects on the surfactant system. Am Rev Respir Dis 129:805-810

40. Clandinin MT, Field CJ, Hargreaves K, Morson L, Zsigmond E 1985 Role of diet fat in subcellular structure and function. Can $\mathbf{J}$ Physiol Pharmacol 63:546-552

41. Kehrer JP, Autor AP 1978 The effect of dietary fatty acids on the composition of adult rat lipids: relationship to oxygen toxicity. Toxicol Appl Pharmacol of adult rat lipic

42. Del Maestro RF 1980 An approach to free radicals in medicine and biology. Acta Physiol Scand [Suppl] 492:153-163

43. Halliwell B, Gutteridge JMC 1985 Free radicals in biology and medicine. Clarendon Press, Oxford, pp 139-189 